\title{
The effect of bottom sediments on the content of heavy metals in meadow soils
}

\author{
Katarzyna Kabzińska ${ }^{1}$, Małgorzata Szczesio ${ }^{1}$, Jacek Świętosławski ${ }^{1}$, Anna Turek ${ }^{1}$ \\ ${ }^{1}$ Lodz University of Technology, Institute of General and Ecological Chemistry; ul. Żeromskiego 116, 90-924 Łódź, Poland; \\ e-mail:kabzinskakasia@gmail.com,malgorzata.szczesio@p.lodz.pl,swietoslawski.jacek@gmail.com,anna.turek@p.lodz.pl
}

(C) 2015 Authors. This is an open access publication, which can be used, distributed and reproduced in any medium according to the Creative Commons CC-BY 4.0 License requiring that the original work has been properly cited.

Received: 28 November 2014; accepted: 23 March 2015

\begin{abstract}
The objects of the study were grasslands situated along the watercourse that collect matter directly from surface runoff from the surrounding fields and ditches. Therefore, the chemical composition of the bottom sediments can be varied. The aim of the study was to determine the content of anthropogenic fractions of selected heavy metals in meadow soils where the material from the watercourse maintenance was stored. Soil samples were collected along the banks of the Witonia "A" Channel (soil with sediment), and 30 meters from the watercourse (soil without sediment). The $\mathrm{pH}$ of soils without sediment was in the range 6.2-6.6, whereas the soil with sediment had a $\mathrm{pH} \geq 7.0$. The content of organic matter was $5.7-31.5 \%$. The concentration of anthropogenic fractions of elements was determined by atomic absorption spectrometry after extraction with a $(1+4) \mathrm{HCl}$ solution. The anthropogenic enrichment coefficients (AEC) calculated in relation to the geochemical background level, were within the range: $0.9-2.8$ for $\mathrm{Zn}, 1.2-3.5$ for $\mathrm{Cu}, 0.7-3.1$ for $\mathrm{Pb}, 1.0-2.8$ for $\mathrm{Ni}$ and $0.3-0.9$ for $\mathrm{Cd}$. The AEC values for lead, copper, cadmium and nickel were usually higher in samples without sediment. A significant correlation between the metal and organic content $\left(R^{2}=0.7-0.9\right)$ was found. On two sites, the level of heavy metals under investigation shows a significant local influence from anthropogenic pressure.
\end{abstract}

Keywords: soil, bottom sediment, anthropogenic fractions of metals, AAS method

\section{INTRODUCTION}

The study of the chemical composition of bottom sediments in inland water basins is the subject of numerous works in the field of geology, hydrology, agriculture and environmental protection (Middelkoop 2000, Dauvalter \& Roqnerud 2001, Głosińska \& Siepak 2006, Dzidowska \& Noga 2008, Pisarek 2008, Świetlik et al. 2009, Ibragimow et al. 2010, Kozak et al. 2012, and Wojtkowska 2014). Part of the work concerns the analysis of the soils on which bottom sediment was used as reclamation material (Madeyski et al. 2008, Gałka 2010, Baran \& Tarnawski 2012). The negative consequences of the accumulation of pollutants in the sediments are not limited to the aquatic environment. During a flood, sediments are re-suspended and deposited on floodplains. The deposited material contains mainly a fine-grained fraction, with a high ion exchange capacity with respect to the impurities present in ionic forms. Therefore, there is a danger of a local increase in the content of heavy metals in the soils of floodplains. Changes in the physiochemical conditions in the soil environment increase the mobility of metal ions, and also, accelerate the processes of migration and biological accumulation of pollutants.

The maintenance of watercourses and drainage facilities relies on removing sediments and utilizing them as ameliorative material. The use of bottom sediments for reclamation is possible on the basis of the provisions of the Act on Waste (Ustawa $z$ dnia 14 grudnia 2012 r. ...) in recovery operation $\mathrm{R} 10$ - Land treatment resulting in benefit to 
agriculture or ecological improvement. The quality assessment of bottom sediments is usually in accordance with Polish regulations (Rozporzadzenie Ministra Środowiska $z$ dnia 16 kwietnia 2002 r. ..., Rozporządzenie Ministra Środowiska $z$ dnia 9 września $2002 r$....). In both of these regulations, to assess the quality of sediments or soils, the total amount of metal in the matrix is taken into account. This approach does not take into consideration the differences in the solubility of compounds, and consequently, their migration and bio-availability. To determine available fractions of metals, single extraction and sequential extraction methods are used. To estimate the content of available fractions of metals in soil, extraction with diluted mineral acids is recommended, e.g. $1 \mathrm{~mol} \cdot \mathrm{dm}^{-3}$ hydrochloric acid (PN-92/R-04016, PN-92/R-04017, Snape et al. 2004) or $10 \%$ solution of nitric acid (Ostrowska et al. 1991). To assess the enrichment of urban soils by elements, in relation to their geochemical background, hot hydrochloric acid (1:4) was used (Pasieczna 2003). The same method was used to draw geochemical maps of the Łódź agglomeration (Lis \& Pasieczna 1998).

The main objective of the work was to determine the content of selected metals in meadow soils, as well as to compare the contents of the anthropogenic fractions of the analytes in soil samples contaminated with bottom sediment with those that did not contain the deposit.

\section{STUDY AREA AND METHODS}

The study area is situated in the Łęczyca district, along the Witonia "A" Channel (Bzura Basin). In the autumn of 2011, during the conservation of drainage facilities, bottom sediments were removed, and then placed on the right bank of the channel. The study covered an area 5 kilometers from Witonia village to the mouth of the stream (to the Strzegociński Channel). On the opposite side of the study area, on the left bank of the channel, a repair shop of agricultural machinery, a poultry farm houses and agricultural buildings can be found.

Soil samples were collected in September 2014 from grasslands located along the banks of the watercourse. Six sites were situated directly on the bank of the river and were contaminated with bottom sediments. Another six sampling points were constructed about 30 meters from the bank, without sediment contamination (Fig. 1, Tab. 1).

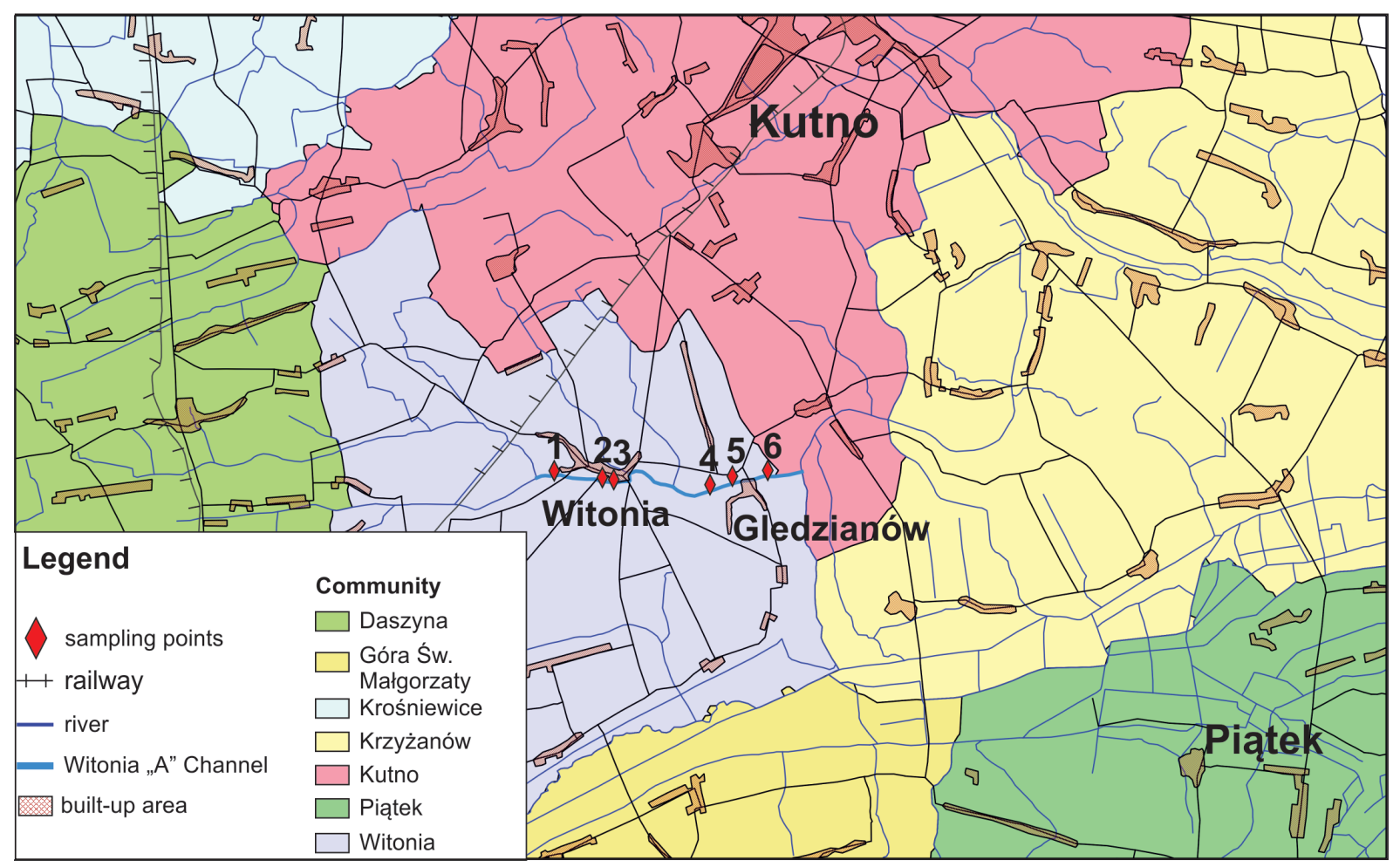

Fig. 1. Localization of the investigated ared 
Table 1

Characteristics of sampling sites

\begin{tabular}{|c|c|c|c|c|c|c|}
\hline \multirow{2}{*}{ No. } & \multirow{2}{*}{ Site } & \multicolumn{2}{|c|}{ Geographical coordinates } & \multirow{2}{*}{ Sample } & \multirow{2}{*}{ pH } & \multirow{2}{*}{$\begin{array}{c}\text { Organic matter } \\
{[\%]}\end{array}$} \\
\hline & & latitude & longitude & & & \\
\hline \multirow{2}{*}{1} & \multirow{2}{*}{ Witonia } & \multirow{2}{*}{$52.146 \mathrm{~N}$} & \multirow{2}{*}{$19.284 \mathrm{E}$} & a & 6.3 & 7.9 \\
\hline & & & & $\mathrm{b}$ & 7.2 & 8.2 \\
\hline \multirow{2}{*}{2} & \multirow{2}{*}{ Witonia } & \multirow{2}{*}{$52.145 \mathrm{~N}$} & \multirow{2}{*}{$19.295 \mathrm{E}$} & $\mathrm{a}$ & 6.0 & 7.9 \\
\hline & & & & $\mathrm{b}$ & 7.4 & 5.7 \\
\hline \multirow{2}{*}{3} & \multirow{2}{*}{ Witonia } & \multirow{2}{*}{$52.145 \mathrm{~N}$} & \multirow{2}{*}{$19.296 \mathrm{E}$} & $\mathrm{a}$ & 6.2 & 7.9 \\
\hline & & & & $\mathrm{b}$ & 7.1 & 6.1 \\
\hline \multirow{2}{*}{4} & \multirow{2}{*}{ Gledzianów } & \multirow{2}{*}{$52.144 \mathrm{~N}$} & \multirow{2}{*}{$19.325 \mathrm{E}$} & a & 6.6 & 31.5 \\
\hline & & & & $\mathrm{b}$ & 7.1 & 22.4 \\
\hline \multirow{2}{*}{5} & \multirow{2}{*}{ Gledzianów } & \multirow{2}{*}{$52.145 \mathrm{~N}$} & \multirow{2}{*}{$19.330 \mathrm{E}$} & a & 7.4 & 14.9 \\
\hline & & & & $\mathrm{b}$ & 7.0 & 23.4 \\
\hline \multirow{2}{*}{6} & \multirow{2}{*}{ Gledzianów } & \multirow{2}{*}{$52.146 \mathrm{~N}$} & \multirow{2}{*}{$19.341 \mathrm{E}$} & $\mathrm{a}$ & 6.3 & 17.3 \\
\hline & & & & $\mathrm{b}$ & 7.2 & 8.3 \\
\hline
\end{tabular}

a - soil sample without sediment,

b - soil sample with sediment.

Samples of $0.5 \mathrm{~kg}$ mass were collected from the surface layer of soil to a depth of $0-20 \mathrm{~cm}$, according to the standard procedure (PN-R-04031:1997). Laboratory soil samples were prepared, according to the same standard procedure. Prior to analysis, the samples were left for two weeks in a dry and airy place, and thus brought to a state of "air dryness". Subsequently, they were sieved to pass through a $2-\mathrm{mm}$ stainless steel screen. The soil $\mathrm{pH}$ was determined in a soil/ $\mathrm{KCl}\left(1 \mathrm{~mol} \cdot \mathrm{dm}^{-3}\right.$, $\mathrm{pH}=5.8-6.0)$ suspension (PN-ISO 10390:1997), using a pH-meter Delta 350 (Mettler). To determine the content of organic matter, the ignition method at $600^{\circ} \mathrm{C}$ was used (Ostrowska et al. 1991). To determine the amount of the anthropogenic fractions of metals, approximately $10 \mathrm{~g}$ of soil was mixed with $50 \mathrm{~cm}^{3}$ of hydrochloric acid $(1+4)$, heated for $1 \mathrm{~h}$ at $90^{\circ} \mathrm{C}$ and passed through a medium qualitative filter, rejecting the first portion of filtrate (Pasieczna 2003). The concentrations of lead, nickel, copper and zinc were determined by the FAAS method with air-acetylene flame, using an AAS spectrometer GBC 932 plus and lamps with a hollow cathode (slit $0.5 \mathrm{~mm}$, lamp currents $3 \mathrm{~mA}-\mathrm{Cu}, 4 \mathrm{~mA}-\mathrm{Ni}, 5 \mathrm{~mA}-\mathrm{Pb}$ and $\mathrm{Zn}$, wavelengths $324.7 \mathrm{~nm}-\mathrm{Cu}, 232.0 \mathrm{~nm}-\mathrm{Ni}, 217.0 \mathrm{~nm}-$ $\mathrm{Pb}, 213.9 \mathrm{~nm}-\mathrm{Zn}$ ). Cadmium was determined by the ETAAS method (slit $0.5 \mathrm{~nm}$, lamp current
$3 \mathrm{~mA}$, wavelengths $228.8 \mathrm{~nm}$ ), using a spectrometer GBC SensAA with argon as a carrier gas. Analytically, pure hydrochloric acid, metal standard solutions (prod. Merck) and deionized water (Polwater device) were used in the analysis.

To assess the degree of pollution of the soil with metals, anthropogenic enrichment coefficients (AEC) were determined. The AEC values were calculated as the ratio of the metal content $\left(X_{i}\right)$ to its geochemical background $(X)$.

The map location was identified using the Quantum GIS ver. 1.8.0-Lisboa (QGIS 2012). Additionally, the thematic layers (rivers, built-up areas, etc.) were downloaded (for free) from CODGIK (Centralny Ośrodek Dokumentacji Geodezyjnej i Kartograficznej).

\section{RESULTS AND DISCUSSION}

According to the recent monitoring studies, more than $40 \%$ of the grassland in Poland is very acidic. While taking its abundance into account, the optimum $\mathrm{pH}$ for grassland soils is 5.5-6.5 (Pietrzak 2012). The $\mathrm{pH}$ of the soil for most of the examined sites was slightly acidic or neutral, whereas the samples collected by the watercourse usually had a higher $\mathrm{pH}$ (Tab. 1). Only in site 5, was this relationship inverse. The correlation between the 
$\mathrm{pH}$ in soils collected at different distances from the river was found $\left(R^{2}=0.62\right)$. Studies were carried out on grassland (hay meadows and pastures). It can therefore be assumed that the higher $\mathrm{pH}$ for meadows results from regular liming. It can be concluded, that from the standpoint of $\mathrm{pH}$, on the area under study, there are favorable conditions for the cultivation of meadow plants. Based on the results of the $\mathrm{pH}$ analysis from the 'monitoring studies', it can also be assumed that the level of mobile fractions of metals should be low. However, our study did not confirm such a relationship. The correlation between the anthropogenic fraction and $\mathrm{pH}$ in the soil does not exceed the value of $R^{2}=0.02$, and for zinc is only $R^{2}=0.11$.

The factor which significantly influences the mobility of heavy metals in soil is organic matter. The results from our studies show that the content of organic substances varied from $5.7 \%$ to $31.5 \%$. The results of metal determination were presented in Table 2. Mineral-organic soils occur in most sites ( $>50 \%$ of samples). However, only three samples have organic matter content above $20 \%$ (organic soils).

The samples under study are not contaminated by cadmium, as demonstrated by the values of an anthropogenic enrichment coefficient below 1.0. On most sites, the level of metal was slightly lower in the samples from the banks of the watercourse. However, a strong correlation between cadmium and organic matter content was found $\left(R^{2}=0.92\right)$ (Fig. 2).
In addition, in the case of nickel, the relationship between the metal concentration and organic matter content $\left(R^{2}=0.92\right)$ was observed (Fig. 3). However, for nickel, the share of anthropogenic fractions of analyte is significant, reaching AEC enrichment values of up to 4 .

Similar correlations between organic matter and metal content were also found for copper, lead and zinc ( $R^{2}$ were $0.82 ; 0.79$ and 0.69 , respectively). However, in the case of zinc concentration, only slight differences in the samples taken at different distances from the channel were observed. Anthropogenic enrichment coefficients for zinc and lead are close to 1.0, except in sites 4 and 5, where their values are 2.5-2.8 (for $\mathrm{Zn}$ ) and 2.3-3.1 (for $\mathrm{Pb})$. In the case of copper, the AECs are within the range 1.2-2.3. In samples No. 4 and 5 they reach values of 3.1-3.5. Strong correlations were also between metal contents in the samples under study. The correlation coefficient ranged from $R^{2}=0.70$ (for $\mathrm{Zn} / \mathrm{Ni}$ ) up to $R^{2}=0.92$ (for $\mathrm{Cd} / \mathrm{Ni}$ ). Extremely high levels of all analyzed elements were found in soil samples collected in sites 4 and 5 (Figs 4-8). An increase in the concentrations of the metals in these places probably is a result of the pollutants introduced by substances used in agriculture (fertilizers, sewage sludge, waste from poultry farms etc.), and not the deposited sediments. This is supported by a lower content of in the samples taken from the bank of the Witonia "A" Channel, despite the slope of analytes the land to the river.

Table 2

Contents of anthropogenic fractions of metals

\begin{tabular}{|c|c|c|c|c|c|c|c|c|c|c|}
\hline \multirow{3}{*}{$\begin{array}{l}\text { Specification } \\
\text { Soil sample }\end{array}$} & \multicolumn{10}{|c|}{ Content of metal } \\
\hline & \multicolumn{2}{|c|}{$\begin{array}{c}\mathrm{Cd} \\
{[\mathrm{mg} / \mathrm{kg} \mathrm{d.m}]}\end{array}$} & \multicolumn{2}{|c|}{$\begin{array}{c}\mathrm{Pb} \\
{[\mathrm{mg} / \mathrm{kg} \text { d.m. }]}\end{array}$} & \multicolumn{2}{|c|}{$\begin{array}{c}\mathrm{Ni} \\
{[\mathrm{mg} / \mathrm{kg} \text { d.m.] }}\end{array}$} & \multicolumn{2}{|c|}{$\begin{array}{c}\mathrm{Cu} \\
{[\mathrm{mg} / \mathrm{kg} \text { d.m. }]}\end{array}$} & \multicolumn{2}{|c|}{$\begin{array}{c}\mathrm{Zn} \\
{[\mathrm{mg} / \mathrm{kg} \text { d.m.] }}\end{array}$} \\
\hline & $\mathrm{a}$ & $\mathrm{b}$ & $\mathrm{a}$ & $\mathrm{b}$ & $\mathrm{a}$ & $\mathrm{b}$ & a & $\mathrm{b}$ & a & $\mathrm{b}$ \\
\hline Min. & 150.0 & 128.6 & 12.9 & 8.6 & 7.9 & 5.9 & 5.4 & 4.9 & 27.5 & 27.3 \\
\hline Max. & 449.7 & 423.8 & 37.1 & 27.2 & 23.2 & 17.8 & 14.2 & 13.4 & 84.0 & 82.2 \\
\hline Mean & 261.5 & 227.3 & 20.9 & 16.2 & 12.0 & 10.2 & 9.3 & 8.1 & 47.5 & 48.0 \\
\hline \multicolumn{11}{|c|}{ Anthropogenic enrichment coefficient (AEC) } \\
\hline Min. & 0.30 & 0.26 & 1.1 & 0.7 & 1.3 & 1.0 & 1.4 & 1.2 & 0.9 & 0.9 \\
\hline Max. & 0.90 & 0.85 & 3.1 & 2.3 & 3.9 & 3.0 & 3.5 & 3.3 & 2.8 & 2.7 \\
\hline Mean & 0.52 & 0.46 & 1.7 & 1.4 & 2.0 & 1.7 & 2.3 & 2.0 & 1.6 & 1.6 \\
\hline $\begin{array}{l}\text { Geochemical background } \\
\text { (Lis \& Pasieczna 1998) }\end{array}$ & \multicolumn{2}{|c|}{500} & \multicolumn{2}{|c|}{12} & \multicolumn{2}{|c|}{2} & \multicolumn{2}{|c|}{4} & \multicolumn{2}{|c|}{30} \\
\hline
\end{tabular}

a - soil sample without sediment,

b - soil sample with sediment. 


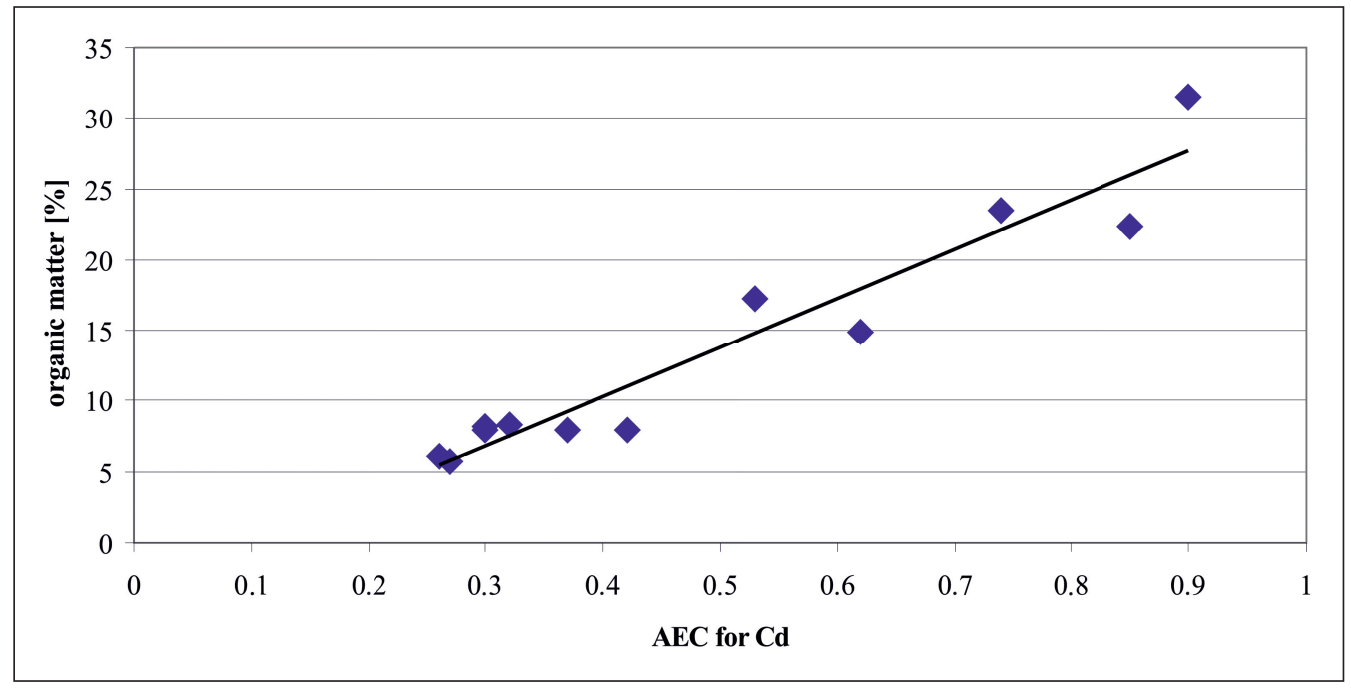

Fig. 2. Organic matter content vs. anthropogenic enrichment coefficient for Cd

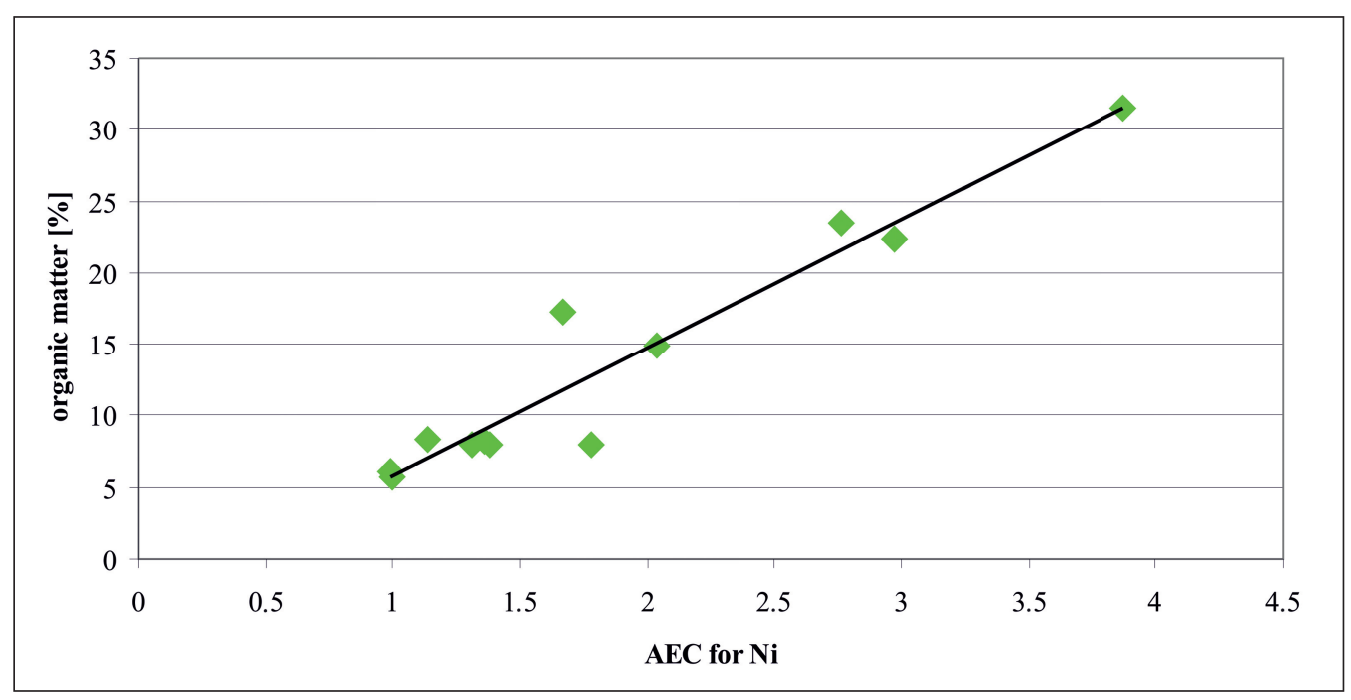

Fig. 3. Organic matter content vs. anthropogenic enrichment coefficient for $\mathrm{Ni}$

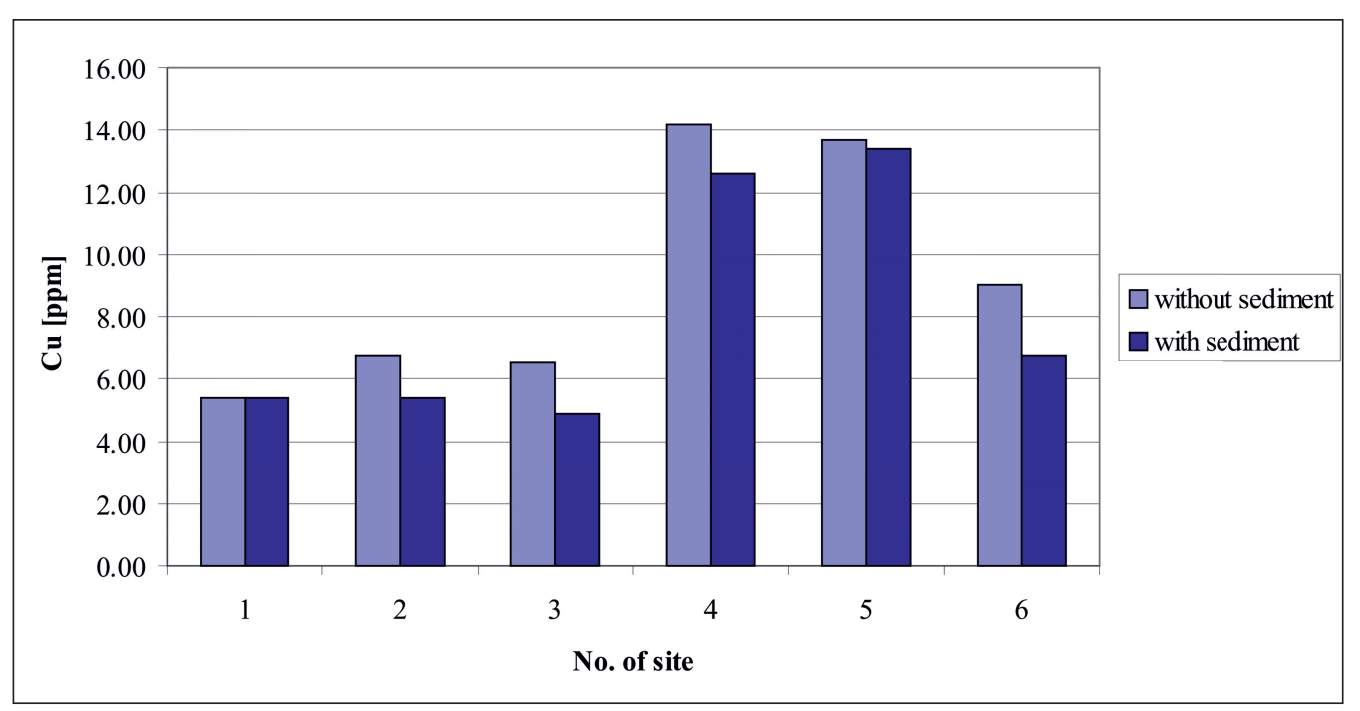

Fig. 4. Copper content in soils 


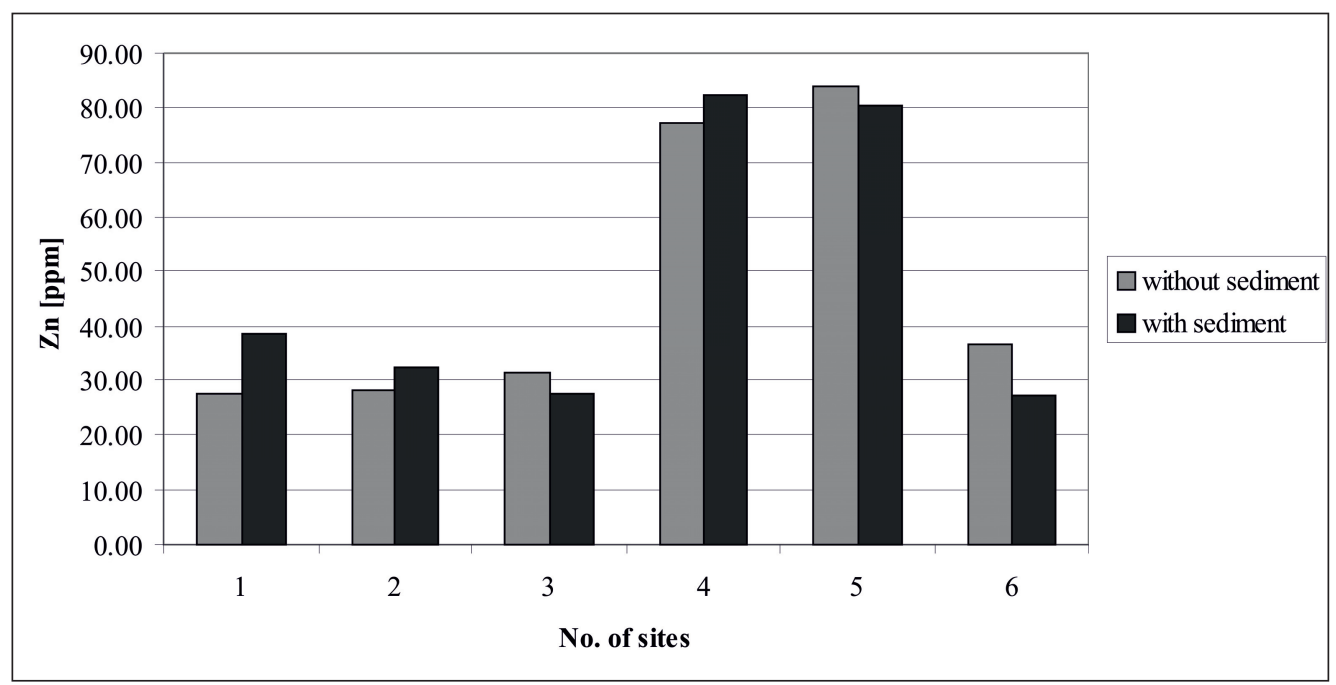

Fig. 5. Zinc content in soils

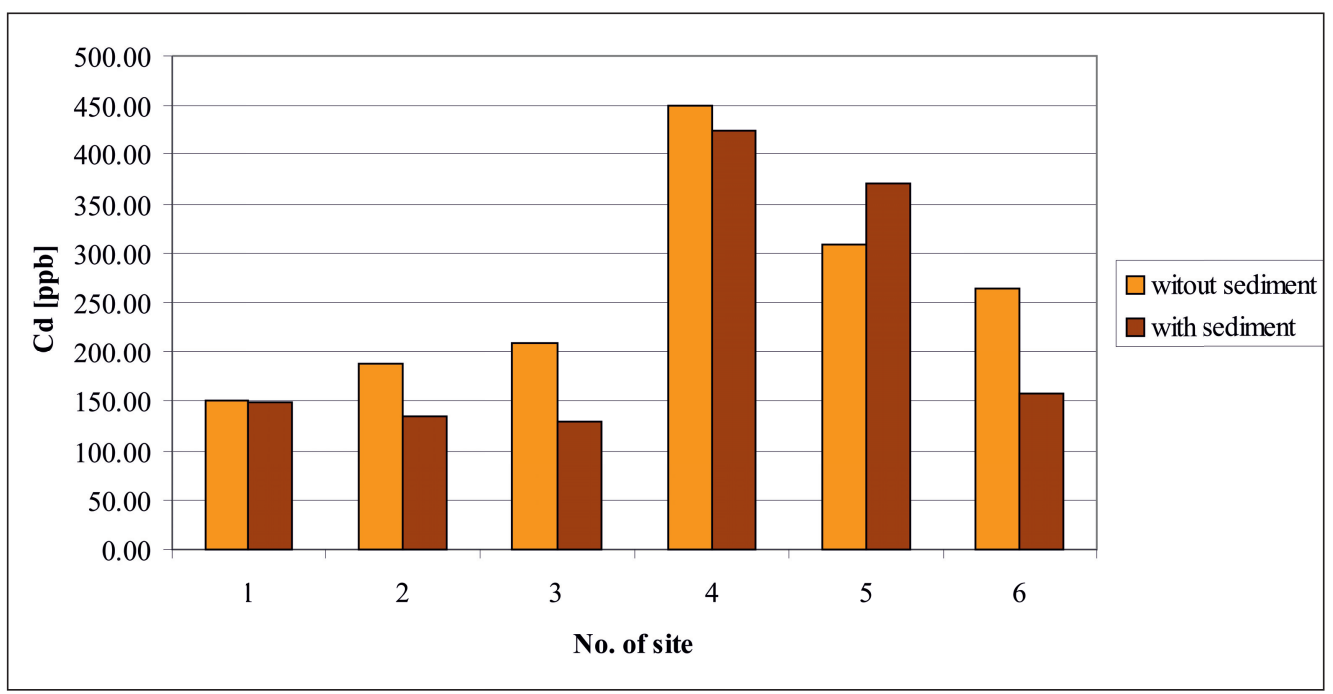

Fig. 6. Cadmium content in soils

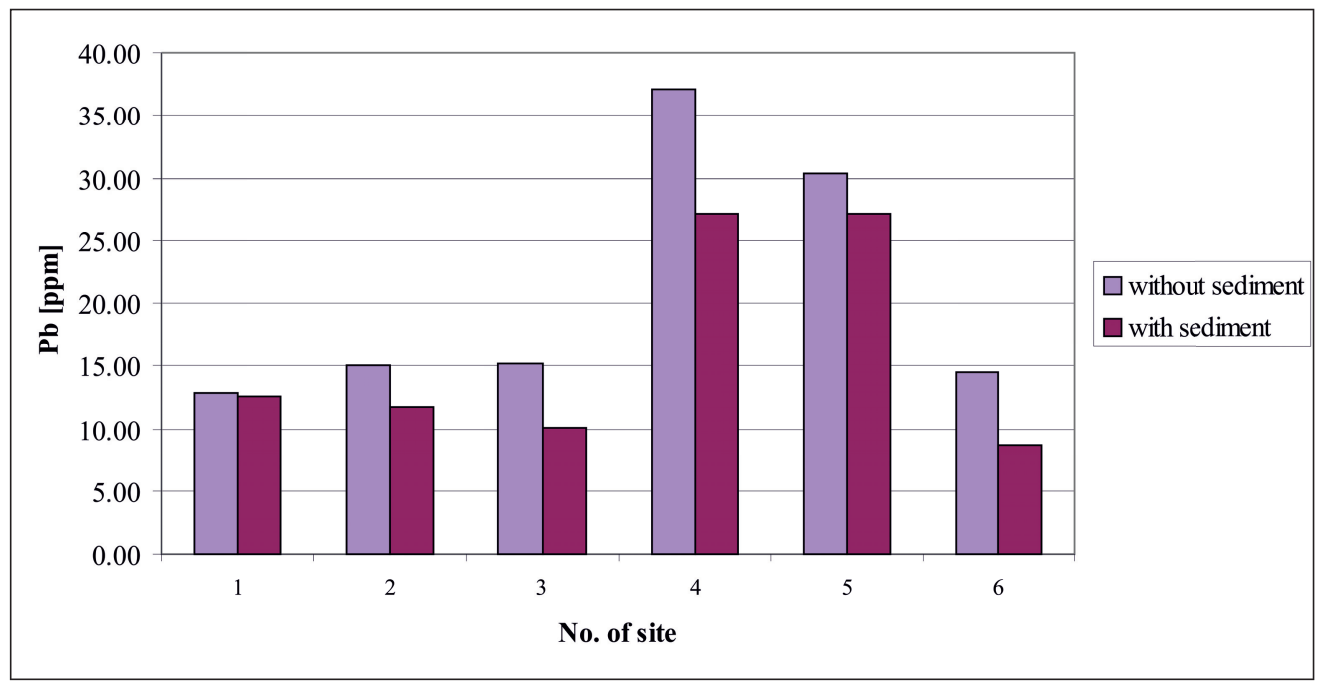

Fig. 7. Lead content in soils 


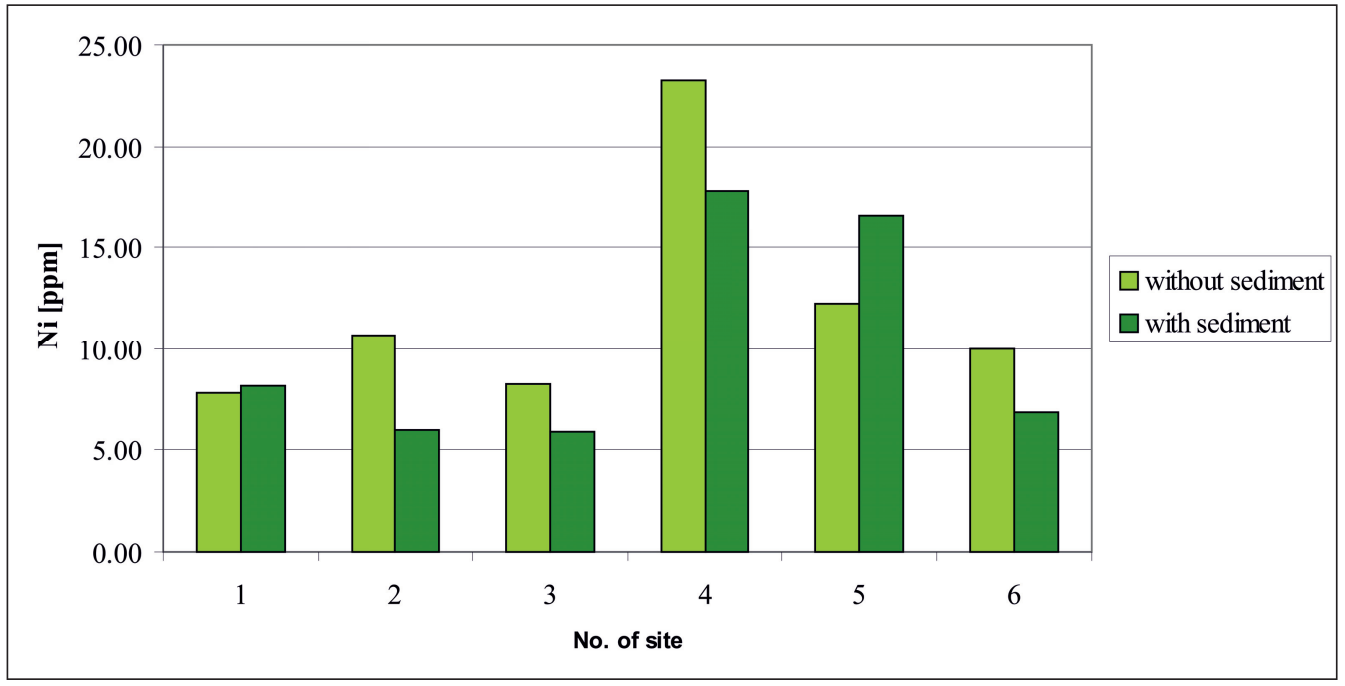

Fig. 8. Nickel content in soils

\section{CONCLUSIONS}

For small reservoirs, such as the Witonia "A" Channel, the silting rate can be significant. This results in the need for frequent dredging. Uncontaminated bottom sediment is usually deposited on the banks. In the case of the Witonia "A" Channel, the chemical analysis of the sediment has not been performed. The presented studies were designed to test whether the method of watercourse maintenance causes contamination of surrounding soils with copper, cadmium, lead, nickel and zinc.

The results of the analysis indicate that the removed sediments had no significant effect on the metal content in the soils under study. In most cases, the amount of analytes on the sites directly on the watercourse (soils containing sediment removed from the Witonia " $\mathrm{A}$ " Channel) is lower than on the sites away from the river. The degree of soil contamination was assessed on the basis of the value of the anthropogenic enrichment coefficient (AEC), which was calculated with respect to the geochemical background. AEC values in most cases are within the range 1-3.9 (the exception of cadmium, with AEC below 0.9). This indicates the impact of anthropogenic contaminations on the metal content in the soils. This is particularly visible on sites 4 and 5 (Fig. 4). The sites under study are away from roads and industrial facilities. Hence, this suggests that the factors determining the high level of the metal concentration in soils (No 4 and 5) are probably agrochemicals and other substances used for fertilization. AECs are correlated with the content of organic matter in the soil $\left(R^{2}=0.69-0.92\right)$. However, there was no relationship between the content of anthropogenic fraction of metals and $\mathrm{pH}$ in the soil. The reason for this is probably high acidity of the extraction method used in the study.

\section{REFERENCES}

Baran A. \& Tarnawski M., 2012. Zawartość metali ciężkich w wyciągach wodnych sporządzonych z osadów dennych Zbiornika Rzeszowskiego. Proceedings of ECOpole, 6, 2, 671-675

Centralny Ośrodek Dokumentacji Geodezyjnej i Kartograficznej - www.codgik.gov.pl.

Dauvalter V. \& Roqnerud S., 2001. Heavy metal pollution in sediments of the Pasvik River drainage. Chemosphere, $42,1,9-18$.

Dzidowska K. \& Noga L., 2008. Ocena warunków geotechnicznych i standardów jakości osadów dennych dla potrzeb modernizacji kanału miejskiego we Wrocławiu. Górnictwo i Geoinżynieria, 32, 2, 99-104.

Gałka B., 2010. Ocena stopnia zanieczyszczenia i możliwości zagospodarowania osadów dennych $\mathrm{z}$ małych obiektów wodnych w parku we Wrocławiu-Pawłowicach. Ochrona Środowiska i Zasobów Naturalnych, 42, 233-239.

Głosińska G. \& Siepak J., 2006. Metale ciężkie w obszarze równin zalewowych. Ekologia, 35, 3, 36-39.

Ibragimow A., Głosińska G., Siepak M. \& Walna B., 2010. Heavy metals in fluvial sediments of the Odra River flood plains - introductory research. Quaestiones Geographicae, 29, 1, 37-47.

Kozak L., Skolasińska K. \& Niedzielski P., 2012. Environmental impact of flood: The study of arsenic speciation in exchangeable fraction of flood deposits of Warta River (Poland) in determination of "finger prints” of the pollutants origin and the ways of the migration. Chemosphere, 89, 3, 257-261. 
Lis J. \& Pasieczna A., 1998. Atlas geochemiczny aglomeracji łódzkiej. Część I. Wydawnictwo Kartograficzne Polskiej Agencji Ekologicznej S.A., Warszawa.

Madeyski M., Michalec B. \& Tarnawski M., 2008. Zamulanie małych zbiorników wodnych i jakość osadów dennych. Series: Infrastruktura i Ekologia Terenów Wiejskich, 11, Komisja Technicznej Infrastruktury Wsi PAN, Kraków.

Middelkoop H., 2000. Heavy-metal pollution of the river Rhine and Meuse floodplains in the Netherlands. Netherlands Journal of Geoscience, 79, 4, 411-428.

Ostrowska A., Gawliński S. \& Szczubiałka Z., 1991. Metody analizy i oceny właściwości gleb i roślin. Katalog. Instytut Ochrony Środowiska, Warszawa.

Pasieczna A., 2003. Atlas zanieczyszczeń gleb miejskich $w$ Polsce. Państwowy Instytut Geologiczny, Warszawa.

Pietrzak S., 2012. Odczyn i zasobność gleb łąkowych w Polsce. Woda-Środowisko-Obszary Wiejskie, 12, 1, 105-117.

Pisarek I., 2008. Antropogeniczne wzbogacenie w metale ciężkie gleb obszarów zalewowych na terenie miasta Opola. Rocznik Ochrona Środowiska, 10, 645-656.

PN-92/R-04016. Analiza chemiczno-rolnicza gleby. Oznaczanie zawartości przyswajalnego cynku. Polski Komitet Normalizacyjny, Warszawa 1992.

PN-92/R-04017. Analiza chemiczno-rolnicza gleby. Oznaczanie zawartości przyswajalnej miedzi. Polski Komitet Normalizacyjny, Warszawa 1992.
PN-ISO 10390:1997. Jakość gleby - Oznaczanie pH. Polski Komitet Normalizacyjny, Warszawa 1997.

PN-R-04031:1997. Analiza chemiczno-rolnicza gleby - Pobieranie próbek. Polski Komitet Normalizacyjny, Warszawa 1997.

QGIS 2012 - http://quantum-gis.pl.

Rozporządzenie Ministra Środowiska $z$ dnia 16 kwietnia $2002 r$. w sprawie rodzajów oraz stężeń substancji, które powoduja, że urobek jest zanieczyszczony. Dz. U. 2002 nr 55, poz. 498.

Rozporzadzenie Ministra Środowiska z dnia 9 września $2002 r$. w sprawie standardów jakości gleby oraz standardów jakości ziemi. Dz. U. 2002 nr 165 poz. 1359.

Snape I., Scouller R.C., Stark J., Riddle M.J. \& Gore D.B., 2004. Characterization of the dilute $\mathrm{HCl}$ extraction method for the identification of metal contamination in Antarctic marine sediments. Chemosphere, 57, 6, 491-504.

Świetlik R., Rabajczyk A. \& Trojanowska M., 2009. Chemiczne frakcjonowanie cynku w osadach rzecznych dorzecza południowej i środkowej Wisły. Przegląd Geologiczny, $57,12,1101-1105$.

Ustawa z dnia 14 grudnia 2012 r. o odpadach. Dz. U. 2013, poz. 21.

Wojtkowska M., 2014. Heavy metals in water, sediments and plants of Zegrzyński Lake. Progress in Plant Protection, $54,1,95-101$. 